\title{
Entrepreneurs Don't Get Tenure: Should Their Professors?
}

\author{
James C Wetherbe (Texas Tech University)
}

KEYWORDS: Entrepreneurship, Innovation, Research Methods, Leadership, Teaching Methods, Higher Education.

Successful entrepreneurs must be constantly open to new ideas, adapt to changing marketplaces, reinvent their businesses and occasionally bet the house. At times, they must take their businesses to the brink (https://eiexchange.com/content/1-entrepreneurialbrinkmanship-lessons-learned-from-best-buy) to survive.

Business and entrepreneurship professors, of necessity, strive to secure tenure, which provides decades of "job for life" security once achieved.

Tenure makes it far too easy to be lazy and complacent. Real entrepreneurs can't afford to be either. FedEx founder Fred Smith was legendary for telling employees - after asking how the job was going -- "Well, don't get comfortable ...we will have to change again soon."

Do business and entrepreneur professors think like Smith? Should those who teach entrepreneurship not "walk the walk" and be willing to play the long game, reinvent themselves and their jobs, grow and persevere?

Does a workplace in which job security can become the Holy Grail encourage this?

Could these dynamics relate to why so many incredible entrepreneurs including Bill Gates, Steve Jobs, Michael Dell, Mark Zuckerberg, Jan Koum, John Mackey, and Larry Ellison drop out of college (http://fundersandfounders.com/entrepreneurs-whodropped-out/) ?

Amusingly, Mark Twain pined, "I have never let school interfere with my education."

\section{A Stark Contrast}

Dick Schulze, founder of Best Buy, was once asked by a professor whether he ever had a threshold for bailing out of Best Buy. When Dick asked for clarification, his

questioner who was researching the topic got straight to the point: "Did you have a predefined point of how much money you were willing to lose before you gave up on Best Buy?"

"There was no such point," Schulze responded. "Failure was not an option. I would never have given up."

This perseverance and determination make phenomenal entrepreneurs like Schulze so different from most of us. But the security of tenure makes it difficult for professors to cultivate his resilience in themselves -- let alone in their students. As contrast, here are some comments l've heard from business professor acquaintances over the years:

"I would like to marry my fiancé but I am going to wait three more years until I get tenure."

"No way will I buy a house until I get tenure in a couple more years."

"I no longer enjoy being a professor, but now that I have tenure there is no way I will give up a guaranteed for job for life."

The last one left a profound impression on me as I realized tenure could handcuff one to a miserable career. And once awarded, tenure removes the incentive to get better and emboldens lazy professors. Consider these actual quotes:

\section{"I don't care if the students complain, I can't be fired."}

"If they make me teach that class, I will generate sufficient complaints I won't have to teach it anymore."

"One of the main reasons I was attracted to becoming a professor was I really liked the job security of tenure."

Ironically absent from the comments is how tenure is

Copyright ( $) 2015$ The Authors. Entrepreneur \& Innovation Exchange is published at EIX.org. This is an open access article under the terms of the Creative Commons Attribution-NoDerivs License, which permits use and distribution in any medium, provided the original work is properly cited and no modifications or adaptations are made. View EIX.org Authorship Terms at https://eix.org/terms 
valued because it protects academic freedom--the original intent. Academic freedom is a core value to be protected. Sadly, tenure has morphed into a job for life benefit. Professor and management guru Peter Drucker questioned if today's version of tenure could be morally justified and suggested there must be a better way to protect academic freedom.

\section{Effect on Future Entrepreneurs}

I often wonder what "job for life security" through tenure does to professors. The obvious impact: only .02\% annual involuntary turnover for tenured professors, compared to 6 to $9 \%$ for the rest of the work force. That's good news for professors, less so for students. Professors' pre-tenure anxiety, and what can become their post-tenure indifference, affect how they teach.

The State of California recently ruled that tenure for $\mathrm{K}-12$ was unconstitutional as it adversely impacts equal opportunity education. The reasoning? If poorly performing teachers can't be terminated, student education suffers.

As a routine practice, I ask students in my classes, "How many of you have experienced an unacceptable professor who was tenured?" Sadly, the response is unanimous.

Most faculty continue to be productive post-tenure. But it is the minority that make the majority look bad. As long as the majority hold on to tenure the minority's behavior remains problematic to higher education.

And unfortunately, these professors shape the attitudes of future professors.

Recently I was asked to attend the doctoral defense of a failed entrepreneur who switched to academia and was presenting a dissertation on why entrepreneurs fail. The student's research identified many useful factors such as the importance of a good network but ironically never mentioned "lack of perseverance." The dissertation was accepted and the new PhD graduate was one step closer to a new goal of becoming a tenured professor.

The practice of tenure started in the late 1700s with good intentions: to protect professors from retribution from donors over matters of doctrine at a time when colleges were run nearly exclusively by religious institutions. But today, the inability to terminate poorly performing professors locks in big costs and makes it difficult for universities to explore more productive teaching techniques. No wonder that Margaret Thatcher abolished tenure in the UK with the Education Reform Act of 1988...yet Oxford and Cambridge remain among the top 10 universities in the world.

Consider these facts:

- A 2011 study of teaching practices (http://www.centerforcollegeaffordability.org/upl oads/Faculty_Productivity_UT-

Austin_report.pdf) at the University of Texas at Austin indicated that UT Austin alone potentially could save $\$ 266$ million a year if it could get half its professors to be as productive in teaching as the top $20 \%$, fire its least productive faculty, and shift their small workload to other professors.

- Evidence shows that non-tenured faculty provide better learning experiences (https://www.insidehighered.com/news/2013/09/ 09/study-finds-students-learn-more-non-tenuretrack-instructors) .

- Tenure limits how nimble colleges can be in deploying their staff to subject areas that will better equip students for employment. As a 2010 study by the Center for College Affordability, a non-profit research center, expressed it: "With a tenure system, colleges are not able to reduce the number of medieval history professors in order to increase the number of information technology and business professors."

- Another related problem is that most business faculties don't try hard enough to attract other outside funding and look to the university to fund their research. External funding improves the quality of research by requiring professors to pass the "sniff test" of those who would fund it. In other words, business schools' research would be better funded and more relevant if they follow the examples set by medical schools (https://hbr.org/2014/12/making-businessschool-research-more-relevant). But with the protection of tenure, it is more difficult to require faculty to obtain external funding.

\section{Resigned Tenure and Glad I Did}

As a researcher and consultant in innovation and change, I often speak with business leaders and entrepreneurs about how technology can revolutionize business practices and improve companies. Before I 
resigned tenure I got plenty of pushback from audience members, who would offer comments such as, "Your innovative uses of technology will eliminate jobs. Easy for you to propose when you have a guaranteed job because of tenure."

Ouch! Tenure was hurting my credibility and this "coveted" benefit felt like an albatross around my neck. I wasn't surprised to learn that in a Wall Street Journal poll, 3 out of 4 subscribers responding would like tenure abolished.

While at the University of Minnesota I learned that I could resign tenure. So over 20 years ago, 13 years after receiving tenure, I resigned it as a principled, personal protest. Though I have to be vetted for it each time I change universities, I simply resign it again.

Now when a business leader challenges me after a speech, I explain that I agree with them and that is why I resigned tenure and converted to a one-year rolling contract. It usually results in a pleasant round of applause-the albatross is gone.

Resigning tenure and becoming a reluctant spokesperson against it have caused controversy as documented in the references below. Operating without the safety net of tenure has kept me mindful as well as motivated that my job security is based upon my performance, just as entrepreneurs must do every day. And it has brought me some opportunities for satisfying professional and personal growth.

EIX is a case in point. Within a few years of retirement, why did I take on the stress of creating this new social media thought leadership platform for entrepreneurs? Besides Dick Schulze asking, it was a challenging way to provide value during the last few years of my career. Instead of coasting towards retirement, this exciting new challenge keeps me on my toes_and awake at night!

To be clear, I am not suggesting being a professor without tenure is any more or less courageous than being an entrepreneur...just that entrepreneurs will take professors more seriously if they don't have tenure.

\section{Golden Parachute Alternative to Tenure}

Critics of eliminating tenure often argue that business executives get golden parachutes or buy-outs if they're terminated. In the academic world, multi-year rolling contracts would give professors some measure of security. In this scenario, promotion from assistant to associate professor (typical tenure time frame) could result in a three-year rolling contract. Promotion to full professor, a five-year rolling contract.

Please note the distinction between a rolling contract and an expiring contract. In an expiring contract, if the contract is not renewed the result is termination. In a rolling contract, if the contract is not renewed the professor would have the number of years left in the contract or a negotiated buy-out for the number of years in the contract (e.g., three or five years).

Professors who don't provide quality learning for students and are perpetually unable to bring in funded research should not be protected by tenure, just as entrepreneurs who cannot keep their customers satisfied, attract funding, or create revenue are out of business.

\section{Summary}

Business schools need to make use of the same tools used in the business world, such as employment contracts, process innovation and better allocation of resources, including how research gets funded.

These schools teach how restrictive work rules and high labor costs for many years made American automotive, electronics and other industries less competitive. Now universities need to adopt their own teachings and end tenure.

Wouldn't it show leadership and set a compelling example if entrepreneurship faculty led the way?

\section{References}

Bashing Tenure as a 'Matter of Public Concern', Inside Higher

(https://www.insidehighered.com/news/2018/03/09/texa s-tech-professor-who-says-university-punished-himopposing-tenure-can-take-case) , Interview and Featured article by Colleen Flaherty, March 2018.

Texas Court Revives Prof's Suit Over Anti-Tenure Speech

(https://www.law360.com/articles/1019567/texas-courtrevives-prof-s-suit-over-anti-tenure-speech) , Law360, Jess Krochtengel, March 2018.

Can a University Punish a Professor because $\mathrm{He}$ 
Criticizes

Tenure?

(https://www.nationalreview.com/corner/professorpunished-tenure-criticism-martin-center-article/)George Leef, National Review, July 2017.

Meet the Professor Who Has Been Punished for Denouncing Tenure

(https://www.jamesgmartin.center/2017/07/meet-

professor-punished-denouncing-tenure/) , George Leef, the James G. Martin Center for Academic Renewal, July 2017

Case Against Tenure

(https://www.insidehighered.com/news/2017/06/07/fede ral-appeals-court-revives-professors-case-againsttexas-tech-over-his-anti) , Inside Higher Ed, Interview and Feature article by Colleen Flaherty, June 2017.

Interview and feature article by Peter Schmidt, "Business School Offers Case Study for Tenure Debate," The Chronicle of Higher Education, November 15, 2014, available at http://chronicle.com/article/Business-School-Offers-

Case/142883/ App. 001-007;

James C. Wetherbe, "The End of Tenure," BizEd, September/October 2013, available at http://www.edigitaleditions.com/i/161013-septoct2013/33. App. 008-009;

James C. Wetherbe, "Tenure System Stifles Business Schools," Invited article, Financial Times, July 14, 2013, available at http://www.ft.com/intl/cms/s/2/85083ab8-d764-11e2-82 79-00144feab7de.html\#axzz3XyScS8m3. App. 010-012;

Jacob Gershman, "New Twist in Texas Tenure Case," Wall Street Journal Law Blog, May 22, 2013.

James C. Wetherbe, "It's Time for Tenure to Lose Tenure," Harvard Business Review HBR.com, Mar. 13, 2013, available at http://blogs.hbr.org/cs/2013/03/its_time_for_tenure_to_I ose_te.html(https://hbr.org/2013/03/its-time-for-tenureto-lose-te) . App. 015-019;

James C. Wetherbe, "Why I Have a Big Problem with Academic Tenure," Invited article, BloombergBusinessweek, Dec. 28, 2012, available at http://www.bloomberg.com/bw/articles/2012-12-28/why -i-have-a-big-problem-with-academic-tenure\#r=nav-r- blog. App. 020-021;

James C. Wetherbe, "Does Academic Freedom Not Apply to Criticism of Tenure?" Invited article, Huffington Post, Dec. 13, 2012, available at http://www.huffingtonpost.com/james-c-

wetherbe/college-professors-tenure-_b_2294070.html. App. 022-023;

Colleen Flaherty, "Rejecting Tenure and Paying for It?" Inside Higher Ed, Dec. 12, 2012, available at http://www.insidehighered.com/news/2012/12/12/lawsui t-texas-tech-professor-says-his-views-tenure-have-costhim-promotions

(https://www.insidehighered.com/news/2012/12/12/laws uit-texas-tech-professor-says-his-views-tenure-havecost-him-promotions) . App. 024-027;

Tom Fowler \& Douglas Belkin, "Tenure Fight Takes New Form," Wall Street Journal, Dec. 7, 2012, available at http://online.wsj.com/article/SB1000142412788732331 6804578163220932595116.html. App. 028-030;

External Resource, "Professor James Wetherbe a real hero!," Education News, Dec. 20, 2012

Susan Svrluga, "A professor hates tenure so much that he's making a federal case of it," (https://www.washingtonpost.com/news/grade-point/wp/ 2015/04/13/a-professor-hates-tenure-so-much-that-hesmaking-a-federal-case-of-it/) The Washington Post, Apr. 13, 2015.

Matthew Watkins, "A Texas Tech Professor Crusades Against Tenure," The Texas Tribune, June 26, 2015, availableanttp://www.texastribune.org/2015/06/26/onetexas-tech-professors-long-crusade-against-ten/

Additional Search Terms: problems with tenure, getting tenure, downside of tenure, deadbeat professors, deadbeat teachers, adjunct professors 